\title{
The early modern period in cell death
}

\author{
Richard A. Lockshin \\ Department of Biological Sciences, St. John's University, Jamaica, New York
}

This essay is a personal and incomplete image of the early modern days in the cell death field, and it hopefully will be followed by other reflections. It is worth recalling for several reasons. Two of the most relevant are that some of the background, published prior to the time that Medline was routinely cataloging articles on the subject, has effectively been lost from modern consciousness. Secondly, some of these aspects, such as involvement of lysosomes, are now resurfacing, and it is perhaps useful not to reinvent the past. Some of the fundamental concepts derive from as far back as the 19th Century, as has been admirably described in other articles (Majno and Joris, 1995; Clarke and Clarke 1996), which are highly recommended to the reader, and the more recent period is covered in the accompanying article (Garfield and Melino, 1997). I would appreciate hearing of references located by others. Circumstances regarding this article did not permit the reproduction of some of the marvelous pictures of our forerunners. Perhaps the occasion will arise for a further presentation of this material. Clarke and Clarke's article, in addition to presenting many similar images is valuable for its reflections on early insightful observations, the waxing and waning of interest in the subject, and the tendency of science to rediscover principles first articulated a century before. Rather than repeat the efforts of these individuals, in the following sections I address a more personal view - one voice among many - of the beginning of the current wave of interest.

\section{Reflections: The late and modest development of the study of cell death}

Very few children, marveling at the development of a frog, concern themselves with the disappearance of the tadpole. Parents far prefer to note every step of development of their child, as opposed to every step of deterioration of themselves or of their parents. Our very human instinctive preference for growth and development relegated the study of cell death to a relatively morbid few. Human preference, however, was not the only millstone. Mitosis is a relatively short and evanescent event, but once it has occurred there are traces of its passing: a single-celled egg becomes two, four, and eight. Using isotopes or other tracers, one can label newly-synthesized DNA and identify it long past the original mitosis. Cell death is far more furtive. Cells simply vanish, usually in less than one hour. Though we may infer, from constant cell number, that cell death equals cell replacement, our emphasis was different. What has changed today is that we used to say, 'Cells die, and are replaced by mitosis.' Today, we are more likely to say, 'Cells die....and are replaced,' emphasizing by the ellipsis that the process of death is likewise interesting. This change in our attitude has come about by virtue of new insights from several fields.

\section{Lysosomal cell death}

For the sake of completeness and as a reflection on trendiness in science, it is worth noting that, contrary to many assumptions, in the 1960's there was a noticeable literature on cell death. The earlier literature focused almost exclusively on the appearance of lysosomes (which had recently been discovered) in dying cells (Kerr, 1965; Lockshin and Williams, 1965a,d; Lockshin, 1969a; Weber, 1969; Schweichel and Merker, 1973; Lockshin and Beaulaton, 1974; Beaulaton and Lockshin, 1977; Hinchliffe, 1981; LeviMontalcini and Aloe, 1981). Kerr, in fact, had been conducting a careful study of lysosomes in dying cells when he observed the distinctly different type of death (Kerr, 1965). The paper is well worth reading. It is not important to elaborate on these findings, except to note that, if one does manual searches through Science Citation Index ${ }^{\mathbb{R}}$, Biological Abstracts ${ }^{\mathbb{R}}$, or similar sources, for the term 'lysosome', one will encounter many instances of cell death now called apoptosis. In particular, involution of post-lactational mammary gland (Helminen et al, 1968; Helminen and Ericsson, 1970, 1971) and hormonoprivic prostate (Sensibar et al, 1990) were examined primarily for the biology of lysosomes. It later became apparent that some of the lysosomes were found in invading phagocytes, but in many tissues there was a clear autophagy of the dying cells, which is relevant today (Zakeri et al, 1995; Bursch et al, 1996), while other lytic mechanisms, including non-lysosomal proteases, have attracted attention. The subsequent rise of thymocytes and lymphocytes as paradigms of cell death eclipsed this approach since in these latter cells early nuclear changes are paramount. Some attention today is returning to the question of destruction of cytoplasm in cells with massive cytoplasm.

\section{Programmed cell death}

Most of the ideas that interest us most today were first asked 2000 years ago, and were articulated in experimental form in the 19th century, but the relevance of an observation is frequently missed. When an observation reaches the threshold of relevance, a particular concatenation of words or a specific phrase renders what has been subliminal, now obvious. This process occurred in the field of apoptosis. The phenomenon was well recognized in the 19th century, as admirably reviewed by Majno and Joris (1995) and Clarke and Clarke (1996) and was even a focus of interest in early developmental biology, as many studies on metamorphosis emphasized. Many of these references are reviewed in the series of articles (Lockshin and Williams, 1964, 1965a-d). For insect metamorphosis, many were notes in Comptes rendus or similar journals, for instance Terre, 1899; Mercier, 1920, 1924, 1928; Mercier and Poisson, 1923; Roubaud, 1932, but some were marvelous, discursive and even garrulous, articles illustrated with elegant watercolors (Hulst, 1906; Pérez, 1910; Feytaud, 1912; Oertel, 1930; Blaustein, 1935; Murray and Tiegs, 1935). By the mid 20th century, 
Glücksmann had called attention to the issue in a vital article entitled 'Cell deaths in normal vertebrate ontogeny' (Glücksmann, 1951) and Saunders had clearly enunciated the problem: In landmark experiments, Saunders noted that, for the differentiation of the chick wing, 'The death clock is ticking' (Saunders, 1966). Picking up these ideas, and depending on the felicitous turn of phrase that characterized Carroll Williams' conversation, we discussed the death of metamorphosing larval cells as 'programmed cell death', recognizing but not clearly enunciating the obvious point that virually everyone had assumed-that any predictable developmental event carries a presumption of genetic background. Saunders and Fallon (1966) followed this reasoning in comparing the interdigital cell death of chicks to the reduced cell death seen in web-footed ducks. Metamorphic cell death was likewise recognized to be species-specific, and was later related to more exotic forms, such as sculpting of wings of butterflies and various sexual dimorphisms. These ideas were followed implicitly as, by the late 1960's the first documentation of a requirement for protein synthesis was detected. However, it took the rise of the power of genetics of Caenorhabditis to focus the attention of the scientific community on the generality of the concepts of (genetic) programming of cell death and the existence of genes controlling cell death.

\section{Apoptosis}

While developmental biologists discussed cell death as perhaps not simply a negative default, but nevertheless only one phenomenon among many, pathologists were more astute. Specifically, Kerr, Wyllie, and Currie generalized the idea (Kerr et al, 1972), building on Kerr's earlier interest in 'shrinkage necrosis' (Kerr, 1971) and noting specifically that most physiological cell deaths followed a common morphological pattern. This was a brilliant insight, which they had the imagination to grace with a term, apoptosis, befitting the originality of their observation. From this insight the medical community first heard that most cell deaths are likely not accidental. The importance of this insight nevertheless lay fallow a few more years. An occasional review and, by 1981, a book (Bowen and Lockshin, 1981), indicated increasing but not massive interest. While much of the scientific community ignored the problem that common morphologies imply common mechanisms to be identified (Schweichel and Merker, 1973; Lockshin and Beaulaton, 1981), the gradual accumulation of mechanistic information finally led to two very important changes in our attitude. First, recognition of a requirement for protein synthesis led to the appropriate but nevertheless groundbreaking identification of a genetics of cell death; and, second, association of the common morphology with a relatively straightforward means of identifying apoptosis led to an explosive recognition of the frequency of apoptosis.

\section{Apoptosis and DNA degradation}

Natural concern for human well being drives and consequently controls our investment in scientific enterprise. Thus a major impact occurred when Wyllie and his colleagues, using cells whose fate powerfully affected our well-being both positively and negatively, established that the peculiar nuclear morphology of apoptosis translated into an organized destruction of the DNA. Isolating by density the condensed apoptotic cells, they found that the DNA fragmented into the now well-known nucleosomal ladder rather than into the randomly cut DNA smear generated when necrotic cells were studied. Although we now know that the primacy of this step is often less urgent in cells with more massive cytoplasm, the observation by Arends, Morris, and Wyllie (1990) was a landmark for several reasons. It established a mechanism for one of the most striking characteristics of classical apoptosis, and established that it was under tight control; it established that the death of thymocytes was clearly not simply an abandonment of maintenance; and, perhaps most important, it established a rather simple means by which high frequency cell death could be detected by most laboratories. From this paper ensued the rapid identification of apoptosis in many varied systems. Apoptosis had become a general phenomenon. More importantly, the death of cells was apoptotic during the differentiation and maturation of the immune system, during suppression of the immune system by glucocorticoids and other mechanisms, in cancerous cells and in tumors, and during many other pathological states. Thus understanding of the mechanisms of apoptosis had clear medical implications (Kerr et al, 1972; Wyllie, 1987). Shortly thereafter, recognition that cell death in AIDS was apoptotic would lend further impetus to these studies. This aspect has been reviewed recently (Ameisen et al, 1995; Gougeon, 1995).

\section{Early suggestions of a genetics of cell death}

Although adaptation of the techniques of the nascent molecular biology led between 1966 and 1970 to identification of a requirement for protein synthesis in the deaths respectively of tadpole tail tissues, insect muscles, and thymocytes (Tata, 1966; Lockshin, 1969b; Munck, 1971, and later to be recognized as valid for neuronal cell death as well), true appreciation of the fact that cell death was not simply a pathological embarrassment had to await unequivocal recognition of cell death genes. This acknowledgment derived from, first, establishment of the complete cell lineage of Caenorhabditis (Brenner, 1974; Sulston and Horvitz, 1977; Sulston et al, 1983); second, recognition in this lineage that some cells routinely died shortly after their birth; and third, identification of mutations that altered all cell deaths (Horvitz et al, 1983; Ellis and Horvitz, 1986), with the inference and ultimately rapid identification of genes that controlled cell death in general.

\section{The genetics of cell death}

Even before the genes were sequenced, the formal classical genetics of cell death in Caenorhabditis had changed our attitude toward programmed cell death. In the original concept, cells followed a defined and presumptively but not explicitly genetically controlled sequence to their deaths, but 
Horvitz, Ellis, and colleagues stated categorically: thirteen percent of the somatic cells in Caenorhabditis died during embryonic development, and all of these deaths were under the control of a handful of genes. Thus animals could select for mechanisms by which cells could die. A small number of genes, acting in concert, could kill a cell. A very small number of genes prevented the death of cells, and these genes were turned on or off by a limited number of regulating genes. Cell death was genetically controlled and simple. More importantly, it appeared, by extrapolation of the implications of the cell death-preventing gene ced- 9 , that all cells could commit suicide, and were normally prevented from doing so. Once the first of these genes was sequenced, the comparison became more urgent.

\section{Other observations that changed the attitude toward cell death}

Several other factors combined in rapid succession to change attitudes and call attention to the field. Cell death was linked to cancer, and malignancy was tightly associated with cell death-regulating mechanisms. Second, neural sciences discovered that the massive cell death in embryonic development and perhaps in aging was part of the same phenomenon. Third, several observations of apoptosisactivating or inactivating genes in viruses and bacteria coalesced into the recognition of an evolutionary oneupmanship in which cellular self-destruction evolves as a process involved in an organism's damage control, while invaders try to block the process. Finally, the groups came together in a series of meetings, of which the first was one on Multistep Carcinogenesis in Sardinia in 1989.

\section{$\mathrm{Bcl}-2$}

The discovery that a major cause of B cell lymphoma was a translocation that extended the life span of B lymphocytes was a true attention grabber (Korsmeyer, 1992). It unequivocally tied apoptosis to cancer in one of the three potentially interesting ways (the other two being the possibility that cells invade new areas by provoking cell death, and the theoretical possibility of evoking apoptosis specifically among tumor cells). By paralleling the story of ced-9 (Hengartner et al, 1992), it suggested that the genetics of cell death in mammals was likewise inherently simple or comprehensive. Finally, it led to the recognition of a yin-yang regulation of cell death, wherein monomeric related proteins dimerize, with the composition of the dimer determining the fate of the cell.

The more-or-less contemporaneous discoveries of the immunocompetent means of self-regulation, Fas and FasL, together with association of proliferation disorders linked to these genes, and other potent oncogenic mutations of p53, rapidly joined the growing sense that normal and malignant growth were played out in a seesaw between growth promoting and apoptosis inducing influences of several genes (see Stewart, 1994; Podack, 1995; Meikrantz and Schlegel, 1995; Lee and Bernstein, 1995 for readily available recent reviews).

\section{Cell death genes are conserved}

Identification of the first mammalian anti-apoptosis gene, bcl-2, highlighted two points of interest. From an intellectual standpoint, there was some formal similarity between the genetic system of the nematode and mammalian cell death. $\mathrm{Bcl}-2$ was identified as a constitutively up-regulated gene causing a B cell lymphoma, and this form of cancer was characterized not by increased mitotic rate but by depressed rate of normal expiration of lymphocytes. Thus mammals possessed a cell death suppressing gene, bcl-2, functionally analogous to ced-9-a powerful incentive to assume that mammalian cell death was likewise simple in control. The medical and therefore financial incentive was the realization that, for the lymphoma at least, it was aberrance of cell death that caused the cancer. The sequencing of ced- 9 indicates that the similarity may be more than formal. The formal and physical parallelism of nematode and mammalian mechanisms of cell death (Vaux et al, 1992; Hengartner and Horvitz, 1994) for bcl-2 and ced-9; see reviews in this journal for references to ced-3 and ICE) led to a sense of the conservation of the pathways, with the implications of high importance normally attributed to conserved mechanisms.

Elucidation of the sequence of ced-3 provided the most recent major surprise and incentive. Ced-3 proved to be homologous to a known mammalian protease. We are well aware that genes that are central to cell function are conserved, and numerous laboratories quickly pursued the implication. We now know that blocking the ICE protease or a close relative can often prevent or seriously impede cell death, and that the structural and functional homology is sufficiently close that the mammalian enzyme can restore function in ced-3 loss of function mutant nematodes (Yuan et al, 1993; Xue et al, 1996). Likewise, the mammalian bcl-2 can partially restore loss of function mutations of ced9 (Vaux et al, 1992; Hengartner and Horvitz, 1994). Thus the generalization and the conservation both appear to be very tight.

\section{Putting it together: Sardinia}

Several meetings marked the new awareness, but many attendees attribute the new impact of the field to a relatively small meeting on chemical carcinogenesis held in Sardinia in 1989. The organizers of this meeting, Amedeo Columbano and Giovanna Ledda-Columbano, had secured the attendance of representatives of the disparate branches of the field. Scientists from Europe, America, Oceania, and Asia were present, and discussions were open and extensive, and the guests came away feeling that a threshold had been crossed. Subsequent meetings at Cold Spring Harbor (organized by Frederick Cope and David Tomei) and a Keystone meeting and Gordon Conference crystallized this sentiment.

\section{Where we stand today}

We now average 7000 publications per year, two journals and several repeating meetings are devoted to the subject, and societies are forming in Europe and the United States. We consider cell death to be an important player in many major 
diseases. In many degenerative diseases, even those previously presumed to be necrotic, we now recognize the signature of apoptosis, clearly suggesting that we may be able to identify an earlier signature and intervene or at least buy time. We recognize many types of cancer, especially the redoubtable p53-fas cancers, to turn around the question of cell death, and we seek means to target cell death for therapeutic control. In many systems, cell death and cell growth are intimately linked. In all of these systems, we recognize many signals triggering cell death, and a few means by which cell death is effected. We are just beginning to understand how the signals are transduced and transmitted.

\section{Note added in proof}

Readers whose libraries are reasonably complete should look for the CIBA Foundation Symposium on Cellular Injury, edited by AVS de Reuck and J Knight (J \& A Churchill, London, 1964). This book featured many of the major researchers at the time, and focused heavily on cell death as a lysosomal phenomenon. A particularly charming article is one by Marcel Bessis, entitled 'Studies on cell agony and death: An attempt at classification' (pp 287-328 including discussion). Bessis clearly understood the difference between the act of dying and the dead cell, and he also presented excellent phase micrographs of apoptotic cells. JD Biggers also had a chapter entitiled 'Normal cell death' and Edgar Zwilling, one on 'Controlled degeneration during development'.

\section{Acknowledgements}

I am grateful for the helpful comments of (in alphabetical order) John Kerr, Andrew Wyllie, and Zahra Zakeri, and, for the courteous provision of references and useful information, Peter Clarke and David Vaux.

\section{References}

Ameisen J-C, Estaquier J, Idziorek T and De Bels F (1995) Programmed cell death and AIDS: significance, perspectives and unanswered questions. Cell Death Differ. 2: 9-22

Arends MJ, Morris RG and Wyllie AH (1990) Apoptosis: The role of the endonuclease. Am. J. Pathol. 136: 593-608

Beaulaton J and Lockshin RA (1977) Ultrastructural study of the normal degeneration of the intersegmental muscles of Antheraea polyphemus and Manduca sexta (Insecta, Lepidoptera) with particular reference to cellular autophagy. J. Morphol. 154: 39-58

Blaustein W (1935) Histologische Untersuchungen über die Metamorphose der Mehlmotte Ephestia kühniella Zeller. Z. Morph. ükol. Tiere 30: 333-354

Bowen ID and Lockshin RA eds (1981) Cell Death in Biology and Pathology (Chapman and Hall; London and New York)

Brenner S (1974) The genetics of Caenorhabditis elegans. Genetics 77: 71-94 (Abstract)

Bursch W, Ellinger A, Kienzl H, Torok L., Pandey S, Sikorska M, Walker R and Hermann RS (1996) Active cell death induced by the anti-estrogens tamoxifen and ICl 164384 in human mammary carcinoma cells (MCF-7) in culture: The role of autophagy. Carcinogenesis 17: 1595-1607

Clarke PGH and Clarke S (1996) Nineteenth century research on naturally occurring cell death and related phenomena. Anatomy and Embryology 193: 81-99

Ellis HM and Horvitz HR (1986) Genetic control of programmed cell death in the nematode. C. elegans. Cell 44: 817-829

Feytaud J (1912) Contribution à l'étude du termite Lucifuge (anatomie, fondation de colonies nouvelles). Arch. Anat. Microscop. 13: 481-607

Garfield E and Melino G (1997) The growth of the cell death field: an analysis from the ISI-Science Citation Index. Cell Death Differ. 4: 352-361
Glücksmann A (1951) Cell deaths in normal vertebrate ontogeny. Biol. Rev. Cambridge Phil. Soc. 26: 59-75

Gougeon ML (1995) Does apoptosis contribute to CD4 T cell depletion in human immunodeficiency virus infection? Cell Death Differ. 2: 1-8

Helminen HJ, Ericsson $\mathrm{JL}$ and Orrenius S (1968) Studies on mammary gland involution. IV. Histochemical and biochemical observations on alterations in lysosomes and lysosomal enzymes. J. Ultrastruct. Res. 25: 240-252

Helminen HJ and Ericsson JL (1970) Quantitation of lysosomal enzyme changes during enforced mammary gland involution. Exp. Cell. Res. 60: 419-426

Helminen HJ and Ericsson JL (1971) Effects of enforced milk stasis on mammary gland epithelium, with special reference to changes in lysosomes and lysosomal enzymes. Exp. Cell. Res. 68: 411-427

Hengartner MO, Ellis RE and Horvitz HR (1992) Caenorhabditis elegans gene ced-9 protects cells from programmed cell death. Nature 356: 494-499

Hengartner MO and Horvitz HR (1994) Activation of C. elegans cell death protein CED- 9 by an amino-acid substitution in a domain conserved in $\mathrm{Bcl}-2$. Nature 369 : $318-320$

Hinchliffe JR (1981) Cell death in embryogenesis. In: Cell Death in Biology and Pathology, eds. ID Bowen and RA Lockshin (Chapman and Hall, London) pp. $35-78$

Horvitz HR, Sternberg PW, Greenwald IS, Fixsen W and Ellis HM (1983) Mutations that affect neural cell lineages and cell fates during the development of the nematode Caenorhabditis elegans. Cold. Spring. Harb. Symp. Quant. Biol. $48 \mathrm{Pt}$ 2: $453-463$

Hulst FA (1906) The histolysis of the musculature of Culex pungens during metamorphosis. Biol. Bull. 11: 277-304

Kerr JFR (1965) A histochemical study of hypertrophy and ischaemic injury of rat liver with special reference to changes in lysosomes. J. Path. Bact. 90: 419-435

Kerr JFR (1971) Shrinkage necrosis: A distinct mode of cellular death. J. Pathol. 105: $13-20$

Kerr JFR, Wyllie AH and Currie AR (1972) Apoptosis: a basic biological phenomenon with wide-ranging implications in tissue kinetics. Br. J. Cancer 26: 239-257

Korsmeyer SJ (1992) Bcl-2 initiates a new category of oncogenes: Regulators of cell death. Blood 80: 879-886

Lee JM and Bernstein A (1995) Apoptosis, cancer and the p53 tumour suppressor gene. Cancer Metastasis Rev. 14: 149-161

Levi-Montalcini R and Aloe L (1981) Mechanism(s) of action of nerve growth factor in intact and lethally injured sympathetic nerve cells in neonatal rodents. In: Cell Death in Biology and Pathology, eds. ID Bowen and RA Lockshin (Chapman and Hall, London and New York) pp. 295-327

Lockshin RA (1969a) Lysosomes in insects. In: Lysosomes in Biology and Pathology, eds. JT Dingle and HB Fell (North Holland Publishing, Amsterdam) pp. 363-391

Lockshin RA (1969b) Programmed cell death. Activation of lysis of a mechanism involving the synthesis of protein. J. Insect Physiol. 15: 1505-1516

Lockshin RA and Beaulaton J (1974) Programmed cell death. Cytochemical evidence for lysosomes during the normal breakdown of the intersegmental muscles. J. Ultrastruct. Res. 46: 43-62

Lockshin RA and Beaulaton J (1981) Cell death: questions for histochemists concerning the causes of the various cytological changes. Histochem. J. 13: $659-666$

Lockshin RA and Williams CM (1964) Programmed cell death. II Endocrinepotentiation of the breakdown of the intersegmental muscles of silkmoths. J. Insect Physiol. 10: 643-649

Lockshin RA and Williams CM (1965a) Programmed cell death. V. Cytolytic enzymes in relation to the breakdown of the intersegmental muscles of silkmoths. J. Insect. Physiol. 11: $831-844$

Lockshin RA and Williams CM (1965b) Programmed cell death. IV. The influence of drugs on the breakdown of the intersegmental muscles of silkmoths. J. Insect. Physiol. 11: 803-809

Lockshin RA and Williams CM (1965c) Programmed cell death. III. Neural control of the breakdown of the intersegmental muscles. J. Insect. Physiol. 11: 605-610

Lockshin RA and Williams CM (1965d) Programmed cell death. I. Cytology of the degeneration of the intersegmental muscles of the Pernyi silkmoth. J. Insect. Physiol. 11: 123-133

Majno G and Joris I (1995) Apoptosis, oncosis, and necrosis: An overview of cell death. Amer. J. Pathol. 146: 3-15

Meikrantz W and Schlegel R (1995) Apoptosis and the cell cycle. J Cell Biochem 58: $160-174$ 
Mercier L (1920) Variation dans le nombre des fibres des muscles vibrateurs longitudinaux chez Chersodromia hirta Walk. Perte de la faculté du vol. C.R Acad. Sci. Paris 171: 933-936

Mercier L (1924) L'atrophie des muscles du vol après la chute des ailes chez Lipoptena cervi L. (Diptère pupipare). C.R. Acad. Sci. Paris 178: 591-594

Mercier L (1928) Contribution à l'étude de la perte de la faculté du vol chez Carnus hemapterus Nitzsch, Diptère à ailes caduques. C.R. Acad. Sci. Paris 186: 529 531

Mercier L and Poisson R (1923) Contribution à l'étude de l'atrophie des muscles du vol chez les Forficulidae. C.R. Acad. Sci. Paris 177: 1142-1145

MunckA (1971) Glucocorticoid inhibition of glucose uptake by peripheral tissues: Old and new evidence, molecular mechanisms, and physiological significance. Persp. Biol. Med. 14: 265-289

Murray FV and Tiegs OW (1935) the metamorphosis of Calandra oryzae. Quart. J. Microscop. Sci. 77: 405-495

Oertel E (1930) Metamorphosis in the honeybee. J. Morph. Physiol. 50: 295-340

Pérez C (1910) Recherches histologiques sur la métamorphose des muscides (Calliphora erythrocephala Mg.) Arch Zool. Expér. Gén. 5me Série 4: 1-274

Podack ER (1995) Functional significance of two cytolytic pathways of cytotoxic T lymphocytes. J. Leukocyte Biol. 57: 548-552

Roubaud E (1932) Des phénomènes d'histolyse larvaire postnymphale et d'alimentation imaginale autotrophe chez le moustique commun, Culex pipiens. C.R. Acad. Sci. Paris 194: 389-391

Saunders JW Jr (1966) Death in embryonic systems. Science. 154: 604-612

Saunders JW Jr and Fallon JF (1966) Cell death in morphogenesis. In: Major Problems in Developmental Biology (25th Symposium of the Society for Developmental Biology), ed. M Locke (Academic Press, New York) pp. 289

Schweichel JU and Merker HJ (1973) The morphology of various types of cell death in prenatal tissues. Teratology 7: 253-266
Sensibar JA, Liu XX, Patai B, Alger B and Lee C (1990) Characterization of castrationinduced cell death in the rat prostate by immunohistochemical localization of cathepsin D. Prostate 16: 263-276

Stewart BW (1994) Mechanisms of apoptosis: Integration of genetic, biochemical, and cellular indicators. Journal of the National Cancer Institute 86: 1286-1296

Sulston J and Horvitz HR (1977) Postembryonic cell lineages of the nematode Caenorhabditis elegans. Dev. Biol. 56: 110-156

Sulston JE, Schierenberg J, White J and Thomson N (1983) The embryonic cell lineage of the nematode Caenorhabditis elegans. Dev. Biol. 100: 64-119

Tata JR (1966) Requirement for RNA and protein synthesis for induced regression of tadpole tail in organ culture. Dev. Biol. 13: 77-94

Terre L (1899) Contribution à l'étude de l'histolyse de l'histogenèse du tissu musculaire chez l'abeille. C.R. Soc. Biol. (Il série) 51: 896-898

Vaux DL, Weissman IL and Kim SK (1922) Prevention of programmed cell death in Caenorhabditis elegans by human bcl-2. Science 258: 1955-1957

Weber R (1969) Tissue involution and lysosomal enzymes during anuran metamorphosis. In: Lysosomes in Biology and Pathology Vol. I. eds. JT Dingle and HB Fell (Elsevier North Holland, Amsterdam) pp. 437-461

Wyllie AH (1987) Apoptosis: Cell death in tissue regulation. J. Pathol. 153: 313-316

Xue D, Shaham S and Horvitz HR (1996) The Caenorhabditis elegans cell-death protein CED-3 is a cysteine protease with substrate specificities similar to those of the human CPP32 protease. Genes Dev. 10: 1073-1083

Yuan J, Shaham S, Ledoux S, Ellis HM and Horvitz HR (1993) The C. elegans cell death gene ced-3 encodes a protein similar to mammalian interleukin-1bconverting enzyme. Cell 75: 641-652

Zakeri Z, Bursch W, Tenniswood M and Lockshin RA (1995) Cell Death Programmed, apoptosis, necrosis, or other. Cell Death Differ. 2: 87-96 